Original Article

\title{
ISOLATION, SCREENING AND DETERMINATION OF A-AMYLASE ACTIVITY FROM MARINE STREPTOMYCES SPECIES
}

\author{
SATHYA RENGASAMY, USHADEVI THANGAPRAKASAM*
}

Centre for Research and Development, PRIST University, Tamil Nadu, India

Email: ushadevi29@gmail.com

Received: 26 Dec 2017 Revised and Accepted: 15 Mar 2018

\begin{abstract}
Objective: This study was aimed to isolate potent amylase producing Streptomyces from the marine source.

Methods: Soil samples were collected from less explored mangrove regions of Muthupet, Tamilnadu. Isolation of Streptomyces was performed by serial dilution plate technique using starch casein agar (SCA) ( $\mathrm{pH} 7.2$ and temp $28^{\circ} \mathrm{C}$ ). Morphological and biochemical characteristics were studied using Bergey's manual of systematic bacteriology. Preliminary screening and quantification of amylase activities were analysed in selected Streptomyces isolates by starch agar plate and dinitrosalicylic acid (DNS) method respectively.

Results: Totally 65 isolates were separated from the marine soil. Among them, 23 strains showed different morphological features. These strains were subjected to amylase activity. Eight Streptomyces isolates (S1-S8) exhibited positive for amylase activity. The zone of clearance was exhibited in the range of diameters between 4-20 mm. Fermentation was prompted with inorganic salt starch agar, international Streptomyces project (ISP-4) media at $28{ }^{\circ} \mathrm{C}$ and incubated in an orbital shaker at $250 \mathrm{rpm}$ for $96 \mathrm{~h} \mathrm{(pH} \mathrm{7.5)}$. The quantitative estimation of amylase activity was exhibited selected eight isolates in the range between 2.4 $\pm 0.002-5.9 \pm 0.005$ (U/ml). The Streptomyces species S4, S5 and S6 exhibited strong amylase activity in both qualitative and quantitative level.
\end{abstract}

Conclusion: This work motivating the amylase producing Streptomyces are originated in mangroves and it proved Streptomyces sp. S6 has a more efficient source of amylase production.

Keywords: Streptomyces, Isolation, Screening, Quantitative determination, Amylase

(C) 2018 The Authors. Published by Innovare Academic Sciences Pvt Ltd. This is an open access article under the CC BY license (http://creativecommons.org/licenses/by/4.0/) DOI: http://dx.doi.org/10.22159/ijpps.2018v10i4.24447

\section{INTRODUCTION}

Amylase (EC: 3.2.1.1) plays a wide range of biotechnological applications in food industry, fermentation, textile and paper industries and having above $25 \%$ demand on a global scale [1-2]. Amylase has been used successfully in starch saccharification, brewing and distilling industries [3]. Presently, amylase production has reached up to $65 \%$ of the world market and continuously increasing the usage [4]. $\alpha$-amylases have been derived from various sources such as plants, animals and microorganisms. Microbial amylase meet industrial demand [5] as there is a possibility of increasing the levels of microbial enzyme synthesized by classical genetic techniques, continuous culture selection, induction and optimization of growth conditions for the enzyme of interest [6].

Streptomyces are an economically important group of organisms among actinobacteria family. They are responsible for the production of about half of the discovered metabolites, notably antibiotics, antitumor agent, an immunosuppressive agent, enzymes and enzymes inhibitors. This insight has been a driving strength towards other drug discovery platforms including high throughput combinatorial production and rational drug design [7]. Streptomyces are known to produce the array of antimicrobial and antioxidant compounds [8]. Thus, it is crucial that new group of Streptomyces from unexplored or underexploited marine environment be pursued as a resource of novel compound [9].

The occurrence of amylase from Streptomyces and the genus considered as an active source of amylases [10]. Notably, Streptomyces avermitilis, Streptomyces sp. SLBA-08, Streptomyces strain A3, Streptomyces rochei BTSS 1001 are used for the production of amylase. Microbial amylase successfully used in medicinal research $[11,12]$. The most significant bacterial amylases are Bacillus, Streptomyces, Micrococcus, Escherichia, Proteus and Serratia [13,14].

Microbial enzyme technology has in recent years, grown to a multimillion dollar industry, exploration of microbial strains for discovering enzyme with novel properties has come close to the screening programs that multinational firms have been undertaking for the discovery of newer enzymes. The marine Streptomyces species are capable of producing a range of bioactive compounds, as well as enzymes [15]. Streptomyces adopted an incredible quantity of valuable products and are expected to the sources of many commercially important metabolites, including novel enzymes. Development in biology has to a great extent to improve the potential to make libraries of enzyme variants, but a vital challenge is to develop good screening tools that can identify the best performing strain [16].

Multi prospective application and demand pave the mode for growing native amylase production and searching for the more efficient process. Microbial bioprocess can meet more easily the current market demand for industrial enzymes [17]. Specifically, Streptomyces have been used to synthesize amylases $[18,19]$. Hence, the present study made an effort to screen and determine the amylase activity from marine Streptomyces.

\section{MATERIALS AND METHODS}

\section{Chemicals and kits}

Chemicals used in this study of starch casein agar media (SCA), Inorganic salt starch agar media (ISP-4), Iodine and maltose were purchased from Hi-Media (Mumbai-India). Dinitrosalicylic acid (DNS) purchased from Sigma Aldrich, (Mumbai, India). All chemicals were grade and all working reagents were prepared with deionized water.

\section{Isolation and selection of Streptomyces}

Soil samples were collected from Muthupet Mangrove forest (Lat.10 $20^{\prime} \mathrm{N}$ and Long.79 ${ }^{\circ} 35^{\prime} \mathrm{E}$ ) in Tamilnadu during May 2012 situated on the south-east coast of India. Isolation of Streptomyces was performed by serial dilution plate technique using starch casein agar 
(SCA) medium [20]. Based on the colony morphology as white coloured, powdery, dried, and rough, with irregular and regular margins were determined Streptomyces species.

\section{Characterization of marine isolates}

Marine isolates features were studied for morphological, physiological and biochemical characteristics according to the method [21]. Colony color, mycelium nature, texture, shape were complemented to Bergey's manual of systematic bacteriology [22]. Microscopic characterization was experimented by coverslip culture technique [23]. The mycelium structure and spore arrangement were observed through high power oil immersion $(100 \mathrm{X})$ objective by light microscope (Olympus, $\mathrm{CH} 20 \mathrm{i}$ ). Biochemical characterization of isolates was performed by standard methods [24].

\section{Screening of amylase}

Isolated 23 Streptomyces were grown on starch agar medium and incubated at $28{ }^{\circ} \mathrm{C}$ for $72 \mathrm{~h}$. After incubation, $3 \mathrm{ml}$ of $1 \%$ iodine was flooded with each plate, and the development of stainless zone around the colonies indicated amylase production [25].

\section{Flask scale fermentation}

The spores suspensions $\left(\sim 10^{6}\right.$ spore $\left.\mathrm{ml}^{-1}\right)$ of eight Streptomyces inoculums were aseptically transferred individually into $50 \mathrm{ml}$ of medium. Streptomyces isolates were cultured in inorganic salt starch agar, international Streptomyces project (ISP-4) medium (50\% sea water; $\mathrm{pH} 7.5)$. The cells were grown aerobically in 250 $\mathrm{ml}$ Erlenmeyer flasks containing $100 \mathrm{ml}$ medium at $28{ }^{\circ} \mathrm{C}$ and incubated in an orbital shaker at $250 \mathrm{rpm}$ for $96 \mathrm{~h}$. After fermentation, the cells were centrifuged at $5000 \times \mathrm{g}$ for $15 \mathrm{~min}$. The cell supernatant was separated and quantitatively studied amylase activity.

\section{Determination of biomass}

The cells were grown aerobically in $250 \mathrm{ml}$ flask containing $100 \mathrm{ml}$ medium at $28{ }^{\circ} \mathrm{C}$ with continuous shaking in an Orbital shaker $(250$ $\mathrm{rpm})$. Streptomyces growth was monitored by measuring culture turbidity at $\mathrm{OD}_{600 \mathrm{~nm}}$ and estimated the biomass content. During the stationary growth phase, the biomass was collected by centrifugation at $15,000 \times \mathrm{g}$ for $10 \mathrm{~min}$ at $4{ }^{\circ} \mathrm{C}$. The cell suspension was washed twice with distilled water and dried in hot air oven at $80^{\circ} \mathrm{C}$ overnight. The cell dry weight was calculated $100 \mathrm{ml}$ of culture broth $\geq 0.8 \mathrm{OD}_{600 \mathrm{~nm}}$ corresponds to $\mathrm{mg} 100 \mathrm{ml}^{-1}$ of cell dry biomass.

\section{Enzyme assay}

Amylase activity was estimated using the method of [26] with minor modifications. To prepare the reaction mixture 1 millilitre of supernatant was mixed with $1 \mathrm{ml}$ of solubilized starch solution and then incubated at $60{ }^{\circ} \mathrm{C}$ for $10 \mathrm{~min}$. The reaction was stopped by adding $2 \mathrm{ml}$ of dinitrosalicylic acid (DNS) reagent. The mixture was cooled in an ice water bath for $10-15 \mathrm{~min}$ and then centrifuged $5000 \times \mathrm{g}$ for $5 \mathrm{~min}$ at $4{ }^{\circ} \mathrm{C}$. The quantity of enzyme was measured at $540 \mathrm{~nm}$ using UV-Vis Spectrophotometer (Techcomp, 2310), with a blank sample as a reference. One unit of enzyme activity was defined as the amount of amylase needed to produce $1 \mu \mathrm{mol}$ of maltose per min under the assay conditions. Amylase activity were performed in triplicates, values calculated by the mean values along with standard error mean.

\section{RESULTS}

\section{Isolation and identification of Streptomyces}

Totally, 65 isolates were selected from the marine sample. Most of the isolates appeared like Streptomyces. Morphologically versatile 23 isolates selected for amylase screening experiments. The isolates were grown at $\mathrm{pH} 7.2$ and temperature $28{ }^{\circ} \mathrm{C}$. Morphological characteristics of the Streptomyces isolates are given in table 1.

Table 1: Morphological characterization of Streptomyces isolates

\begin{tabular}{|c|c|c|c|c|c|c|c|}
\hline Isolates & Appearance & $\begin{array}{l}\text { Aerial/substrate } \\
\text { mycelium }\end{array}$ & $\begin{array}{l}\text { Size } \\
(\mathrm{mm})\end{array}$ & Shape & Surface & $\begin{array}{l}\text { Reverse } \\
\text { pigment }\end{array}$ & Light microscopy \\
\hline S1 & $\begin{array}{l}\text { White brown color, } \\
\text { powdery }\end{array}$ & Ash with sandal white & 6 & Button & Smooth & Brown & Filamentous \\
\hline S2 & Dark brown with violet & Yellow with brown & 8 & Double ring & Smooth & Pink & Filamentous \\
\hline S3 & $\begin{array}{l}\text { Powdery green with } \\
\text { white }\end{array}$ & Ash with yellow & 5 & Round & Rough & Green & $\begin{array}{l}\text { Rectus with } \\
\text { filamentous }\end{array}$ \\
\hline S4 & Violet with yellow & White with sandal & 9 & Line with dots & Powder & Dark brown & Recti flexible \\
\hline S5 & $\begin{array}{l}\text { Sandal with white } \\
\text { colonies, }\end{array}$ & Grey with cream & 8 & Tiny round & Smooth & Light yellow & $\begin{array}{l}\text { Spiral with } \\
\text { filamentous }\end{array}$ \\
\hline S6 & $\begin{array}{l}\text { Golden yellow with } \\
\text { sandal }\end{array}$ & White with ash & 4 & Round & Smooth & Orange & Filamentous \\
\hline S7 & $\begin{array}{l}\text { Yellow with Brown } \\
\text { color }\end{array}$ & Brown with white & 3 & $\begin{array}{l}\text { Feather with } \\
\text { round }\end{array}$ & Rough & $\begin{array}{l}\text { Pink with } \\
\text { brown }\end{array}$ & $\begin{array}{l}\text { Filamentous with } \\
\text { spiral }\end{array}$ \\
\hline S8 & White with pink & Ash with white & 5 & Root with line & Smooth & Red with pink & Filamentous \\
\hline
\end{tabular}

S1-S8: Streptomyces species code; mm-millimeter.

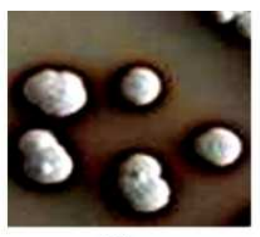

S1

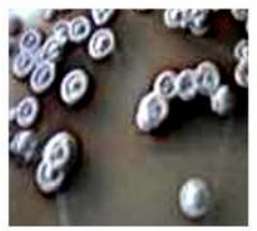

S5

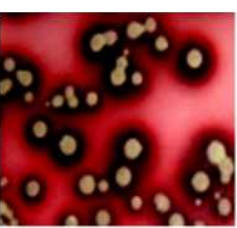

S2

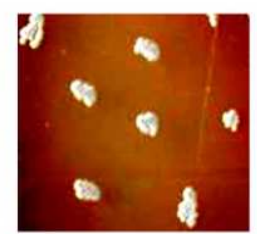

S6

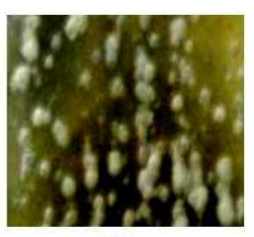

S3

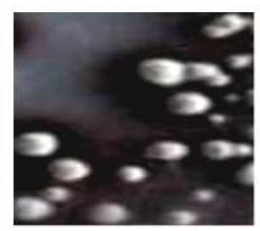

S7

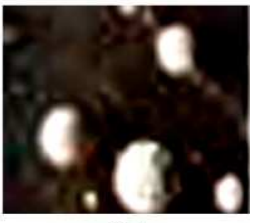

S4

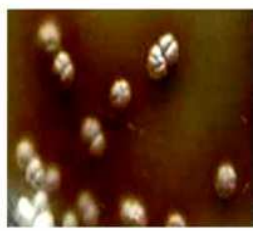

S8

Fig. 1: Colony morphology of Streptomyces isolates on starch casein agar plates, representative isolates of amylase producers associated with mangrove soil; S-Streptomyces species Isolate code; S1, S2, S3, S4, S5, S6, S7 and S8 
The isolates showed well developed aerial and substrate mycelia with sporulation on starch casein agar media. The colony morphology of Streptomyces isolates is given in fig. 1. Microscopic views of spore chains arrangements of Streptomyces appeared like filamentous (F) flexible-rectifexible (RF), and filamentous with spirals (FS) (table 1). Isolates emerged different shapes like round, tiny ring, and button shape colonies, and the texture appeared powdery, rough and smooth spores. Isolates synthesized numerous reverse color pigments like green, yellow, red, golden yellow, brown and violet color on starch casein agar plate (fig. 2).

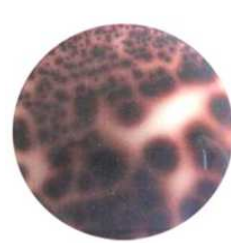

S1

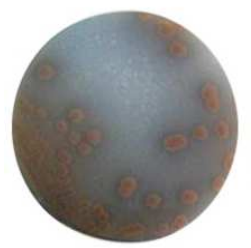

S5

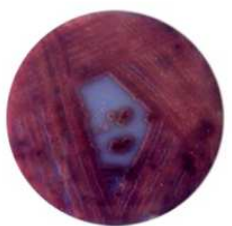

S2

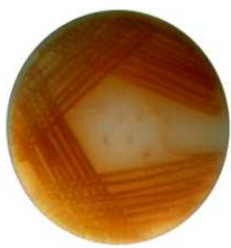

S6

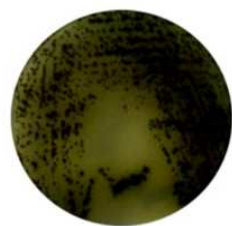

S3

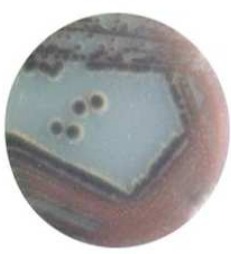

S7

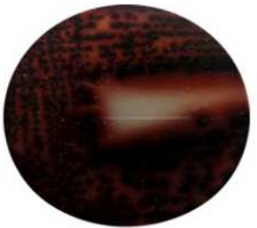

S4

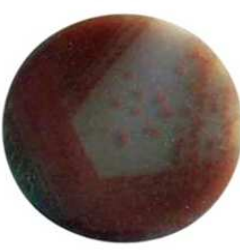

S8

Fig. 2: Reverse side pigmentation on Streptomyces isolates, the pigmented isolates suitable for the identification of Streptomyces on genus level. S1-S8: Streptomyces species code

Biochemical characteristics of the isolates are given in table 2. Isolates are aerobic, G+ve, mesophilic, non-motile and nonendospore forming characteristics. Morphological and biochemical characteristics of marine isolates were appeared similar to the genus Streptomyces. This study provides genus level identification of Streptomyces.

Table 2: Biochemical characterization of Streptomyces isolates

\begin{tabular}{|c|c|c|c|c|c|c|c|c|}
\hline Experiments & S1 & S2 & S3 & S4 & S5 & S6 & S7 & S8 \\
\hline Gram's staining & + & + & + & + & + & + & + & + \\
\hline Endospore & - & - & - & - & - & - & - & - \\
\hline Starch hydrolysis & +++ & +++ & ++ & ++ & ++ & +++ & +++ & + \\
\hline Citrate & + & + & - & - & + & + & + & - \\
\hline Catalase & + & - & - & + & + & + & - & + \\
\hline Urease & + & + & + & + & + & + & + & - \\
\hline Nitrate reduction & + & - & - & + & + & + & - & + \\
\hline CHO Fermentation Glucose & + & - & - & - & + & - & + & - \\
\hline
\end{tabular}

+= Positive, - = Negative. S1-S8: Streptomyces species code.

\section{Screening of amylase activity}

Primary screening of amylase production are given in fig. 3. Among 23 isolates, 8 Streptomyces isolates exhibited positive amylase activity in the starch medium. These potent isolates were displayed various diameters zone, ranging between 4-20 mm. Streptomyces S4, S5 and S6 exhibited higher activity than the other isolates.

Each Streptomyces produced the desirable zone of clearance. Especially, S6 exhibited higher amylase activity.

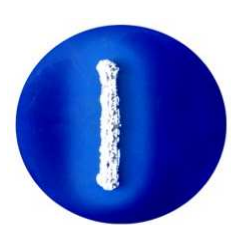

S1

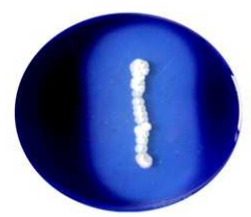

S5

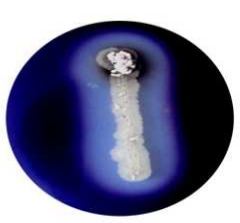

S2

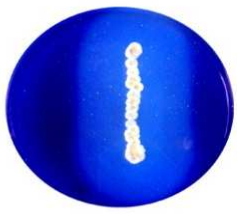

S6

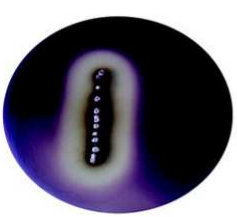

S3

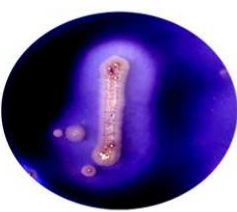

S7

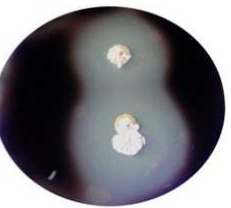

S4

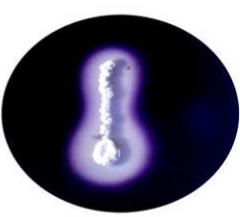

S8

Fig. 3: Screening of amylase producing Streptomyces isolates from mangrove soil. The development of clear zone around the colonies was indicates positive for amylase activity. S1-S8: Streptomyces species code 


\section{Determination of biomass}

The time course profile of eight Streptomyces species was monitored as optical density vs. incubation time (fig. 4). The maximum biomass production was recorded only in Streptomyces sp. S6, it has reached initial stationary phase at 96 $\mathrm{h}$, and the maximum cell dry weight of $0.53 \mathrm{mg} 100 \mathrm{ml}-1$. The $\mathrm{S} 4$, S3 and S8 isolates were reached in the range between 0.41-0.53 mg $100 \mathrm{ml}-1$.

\section{Quantification of amylase activity}

Amylase production was determined roughly (without optimization), the potent isolates produced desirable quantity. The results of extracellular amylase activity by dinitrosalicylic acid (DNS) method are given in table 3. The crude fraction of enzyme absorption was measured at $540 \mathrm{~nm}$, the measurement provides the validation of amylase production. The crude fraction of amylase activity was observed in the range of $2.4 \pm 0.002-5.9 \pm 0.005$ $(\mathrm{U} / \mathrm{ml})$.

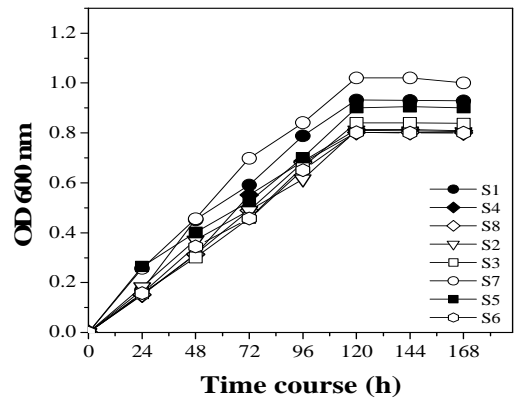

Fig. 4: Time course profile of amylase producing streptomyces isolates, the growth phase was determined with ISP-4 medium. The growth rate was observed regularly at $24 \mathrm{~h}$ time intervals and the concentration was measured at $\mathrm{OD}_{600 \mathrm{~nm}}$ during $24-168 \mathrm{~h}$. The right portion of the curve was observed only in S4-S6, and high level of growth exhibited during $96 \mathrm{~h}$

Table 3: Qualitative and quantitative determination of amylase activity by Streptomyces

\begin{tabular}{|c|c|c|c|}
\hline Isolates & Clear zone (mm) & Cell dry biomass (mg $100 \mathrm{ml}^{-1}$ ) & Enzyme activity (U/ml) \\
\hline S1 & $4.0 \pm 0.81$ & $0.23 \pm 0.003$ & $2.4 \pm 0.002$ \\
\hline S2 & $9.0 \pm 0.26$ & $0.35 \pm 0.004$ & $2.6 \pm 0.005$ \\
\hline S3 & $7.0 \pm 0.31$ & $0.24 \pm 0.003$ & $3.5 \pm 0.001$ \\
\hline S4 & $15 \pm 0.54$ & $0.41 \pm 0.001$ & $4.6 \pm 0.002$ \\
\hline S5 & $18 \pm 0.98$ & $0.51 \pm 0.004$ & $5.6 \pm 0.005$ \\
\hline S6 & $20 \pm 0.12$ & $0.53 \pm 0.001$ & $5.9 \pm 0.009$ \\
\hline S7 & $12 \pm 0.81$ & $0.41 \pm 0.005$ & $4.1 \pm 0.002$ \\
\hline S8 & $9.0 \pm 0.54$ & $0.32 \pm 0.001$ & $3.5 \pm 0.003$ \\
\hline
\end{tabular}

S1-S8: Streptomyces species code; mm-millimetre; mg-milligram; U/ml-Unit/ millilitre, Amylase screening and activity was performed in triplicates and the mean values along with standard error mean (mean \pm SEM., $n=3$ ).

\section{DISCUSSION}

This study was aimed to isolate potent amylase producer from a marine source. Streptomyces produce the incredible source of intercellular and extracellular enzymes vital for industrial and economic use [27]. However, the distribution of Streptomyces in the marine is chiefly unexplored or underexploited habitats be pursued as sources of novel compounds for industrial usage [28]. Mangrove is a high moisture, high salinity and hypoxia to tolerant ecosystem [29] which breeds many kinds of novel microorganisms which are the main source of vital compounds [30]. Many researchers investigated the muthupet mangrove vegetation, isolation and characterization of bioactive compounds from Streptomyces [31-32]. A novel Streptomyces strain was isolated from mangroves soil at Tanjung Lumpur, Malaysia [33].

Morphological and biochemical features of isolated Streptomyces were similar to Bergey's manual of systematic bacteriology [22]. Furthermore, they are ubiquitous in nature and showed a higher diversity in color of colonies, secreted pigments, etc., compared to other bacteria. Strains can be readily differentiated by variation in colors of their aerial and substrate mycelium and based on physiological and biochemical characteristics [34]. The similar microscopic characterization of Streptomyces spore morphology and hyphae features was studied [35].

More studies involving isolation and screening of amylase by starch agar plate. Amylolytic activity was identified by Bacillus subtilis B19 [36]. Amylase production on the agar plate was proved by Aspergillus versicolor and Penicillium sp [37]. Amylase production has been done by numerous strains notably $S$. gulbargensis, Streptomyces strain A3, S. avermitilis, S. rochei BTSS 1001 [38-39]. This work coincided with the similar determination of previous analysis of amylase on starch agar.

Amylase is one of the most significant industrial enzymes. Every year several tons of amylase is used in the various industrial applications in Iran [40]. High level of extracellular amylase production was achieved newly isolated alkali-thermotolerant strain Streptomyces gulbargensis DAS 131[38]. Aquatic actinomycetes were exhibited amylase activity $62.97 \mathrm{U} / \mathrm{ml}$ [41]. Box-Behnken design method highly improved amylase activity $145.32 \mathrm{U} / \mathrm{ml}(\mathrm{pH} 6$, temp $35^{\circ}$ C) [42]. Aspergillus fumigatus NTCC1222 showed highest amylase activity $(164.1 \mathrm{U} / \mathrm{ml})$ was studied [43]. $\alpha$-Amylase was derived from Bacillus sp. BCC 01-50 [44]. Recently highest amylase production was achieved through optimization by $B$. cereus. The production was carried out under submerged state fermentation. The maximum production of amylase was $281.1 \pm 0.65 \mathrm{U} / \mathrm{ml}$ in wheat bran supplemented medium [45].

Analysis of amylase activity in the crude extract, the results provide a significant quantity of amylase. Streptomyces S4, S5 and S6 were exhibited (4.9-5.6 U/ml) activity. Few reports coincide with the present amylase activity. Streptomyces cheonanensis VUK-A was roughly produced $4.3 \mathrm{U} / \mathrm{ml}$ after optimization, reached $11.2 \mathrm{U} / \mathrm{ml}$ [46]. Amylase activity was explored during the short period, significant quantity achieved by Streptomyces sp S4, S5 and S6. The isolates S4, S5 and S6 are considered an efficient for amylase production to the technological application.

\section{CONCLUSION}

In the present study, the marine Streptomyces isolates had the significant ability to produce industrial amylases. Streptomyces are considered as a worthy source for amylases, identified from mangroves. It is enormous importance as secrete extracellular amylases. The results are more virtual and low-cost production of amylase by inexpensive single media without optimization. Further study is in progress to scale up the amylase production using optimization. Therefore, the future work deals with the optimization and improvement of amylase will be explored.

\section{AUTHORS CONTRIBUTIONS}

Sathya Rengasamy and Ushadevi Thangaprakasam were designed and executed the experimental analysis and written the manuscript. 


\section{CONFLICT OF INTERESTS}

No conflict of interest declared

\section{REFERENCES}

1. Rajagopalan G, Krishnan C. Alpha amylase production from catabolic depressed Bacillus subtilis KCC103 utilizing sugarcane bagasse hydrolysate. Bioresour Technol 2008;99:3044-50.

2. Reddy NS, Nimmagadda A, Sambasiva Rao KRS. An overview of the microbial amylase family. Afr J Biotechnol 2003;2:645-8.

3. Gupta R, Gigras P, Mohapatra H, Goswami VK, Chauhan B. Microbial amylases a biotechnological perspective. Process Biochem 2003;38:1599-16.

4. Abdullah $\mathrm{R}$, Shaheen $\mathrm{N}$, Iqtedar $\mathrm{M}, \mathrm{Naz} \mathrm{S}$, Iftikhar $\mathrm{T}$. Optimization of cultural conditions for the production of alphaamylase by Aspergillus niger (BTM-26) in solid state fermentation. Pak J Bot 2014;46:1071-8.

5. Pandey A, Soccol CR, Mitchell D. New developments in solid state fermentation: Bioprocess and products. Process Chem 2000;35:1153-69.

6. Konsoula Z, Liakopoulou Kyriakides M. Co-production of $\alpha$ amylase and $\beta$-galactosidase by Bacillus subtilis in complex organic substrates. Bioresour Technol 2007;98:150-7.

7. Bull AT, Stach JEM, Ward AC, Goodfellow M. Marine actinobacteria; perspectives, challenges, future directions. Antonie Van Leeuwehoek 2005;87:65-79.

8. Sreejetha M, Divya, Veena S, Kokati Venkata BR. The bioactive potential of Streptomyces variabilis-DV-35 isolated from Thottada Marine sediments, Kannur, Kerala. Asian J Pharm Clin Res 2016;9:67-71.

9. Ruan CY, Zhang L, Ye WW, Srivibool R, Duangmal K, Pathomaree $\mathrm{W}$, et al. Streptomyces ferrugineus sp. nov., isolated from mangrove soil in Thailand. Antonie Van Leeuwenhoek 2015;107:39-45.

10. Vigal T, Gil JF, Daza A, Garcia-Gonzalez MD, Martin JF. Cloning characterization and expression of an alpha-amylase gene from Streptomyces griseus IMRU 3570. Mol Gen Genet 1991;225:27888.

11. Chakraborty S, Raut G, Khopade A, Mahadik K, Kokare C. Study on calcium ion dependent amylase from haloalkaliphilic marine Streptomyces strain A3. Indian J Biotechnol 2012;11:427-37.

12. Acharyabhatta A, Kandula SK, Terli R. Taxonomy and polyphasic characterization of alkaline amylase producing marine Streptomyces rochei BTSS 1001. Int J Microbiol 2013;18. http://dx.doi.org/10.1155/2013/276921

13. Van Der Maarel JM, Van Der Veen B, Uitdehaag JC, Leemhuis H, Dijkhuizen L. Properties and applications of starch-converting enzymes of the alfa amylase family. J Bacteriol 2002;94:137-55.

14. Shafiei M, Ziaee AA, Amoozegar MA. Purification and characterization of an organic solvent tolerant halophilic aamylase from the moderately halophilic Nesterenkonia sp. strain F. J Ind Microbiol Biotechnol 2011;38:275-81.

15. Jerry Reen F, Gutierrez-Barranquero JA, Dobson ADW, Adams C, Gara FO. Emerging concepts promising new Horizons for marine biodiversity and synthetic biology. Mar Drug 2015;13:2924-54.

16. Whitehurst RJ, Oort MV. Second Edition. Enzymes in Food Technology. Wiley Blackwell Pub; 2010. p. 44-5.

17. Sarrouh B, Santos TM, Miyoshi A, Dias R, Azevedo V. Up-Todate insight on industrial enzymes applications and global market. J Bioprocess Biotech 2012;4:1-10.

18. Hmidet N, El-Hadj Ali N, Haddar A, Kanoun S, Nasri M. Alkaline proteases and thermostable alpha-amylase co-produced by Bacillus licheniformis $\mathrm{NH} 1$ : characterization and potential application as a detergent additive. Biochem Eng 2009;47:71-9.

19. Oyeleke SB, Auta SH, Egwin EC. Production and characterization of amylase produced by Bacillus megaterium isolated from a local yam peel dumpsite in Minna, Niger state. J Microbiol 2010;2:88-92.

20. Kuster E, Williams ST. Production of hydrogen sulphide by Streptomyces and methods for its detection. Appl Microbiol 1964;12:46-52.

21. Shiriling EB, Gottlieb D. Methods for characterization of Streptomyces species. Int J Syst Bacteriol 1966;16:312-40.
22. Locci R. Streptomyces and related genera. Bergey's manual of systematic bacteriology. In. Baltimore: Williams and Wilkins Company; 1989. p. 2451-508.

23. Kawato M, Shinolue R. A simple technique for the microscopic observation, memoirs of the Osaka University. Liberal Arts Education 1959. p. 114.

24. Williams ST, Goodfellow M, Alderso G, Wellkington EMH, Sneath PHA, Sackins MJ, et al. Numerical classification of Streptomyces and related genera. J Gen Microbiol 1983;129:1743-813.

25. Hankin L, Anagnostaskis SL. The use of solid media for detection of enzyme production by fungi. Mycologia 1975;67:597-607.

26. Miller GL. Use of dinitrosalicyclic acid for determining reducing sugars. Anal Chem 1959;31:426-8.

27. He X, Yu Ou H, Yu Q, Zhou X, Wu J, Liang J, et al. Analysis of a genome island housing genes for DNAS-modification system in Streptomyces lividans 66 and its counterparts in other distantly related bacteria. Mol Microbiol 2007;64:1034-48.

28. Stach JCM, Maldonado LA, Ward AC, Bull AT, Goodfellow M. Williamsia maris sp. nov., a novel actinomycetes isolated from the Sea of Japan. Int J Syst Evol Microbiol 2004;54:191-4.

29. Mu W, Wang $\mathrm{X}$, Xue $\mathrm{Q}$, Jiang $\mathrm{B}$, Zhang $\mathrm{T}$, Miao $\mathrm{M}$, et al. Characterization of a thermostable glucose isomerase with an acidic pH optimum from Acidothermus cellulolyticus. Food Res Int 2012;47:364-7.

30. Li MY, Xiao Q, Pan JY, Wu J. Natural products from semimangrove flora: source, chemistry and bioactivities. Nat Prod Rep 2009;26:281-98.

31. Vijayakumar R, Murugesan S, Panneerselvam A. Isolation, characterization and antimicrobial activity of actinobacteria from point calimere coastal region, East coast of India. Int Res J Pharm 2010;1:358-65.

32. Prabhahar C, Saleshrani K, Enbarasan R. Isolation and characterization of marine actinomycetes from muthuppettai mangroves, Tamilnadu, India. Int J Rec Sci Res 2014;5:906-10.

33. Ser HL, Zainal N, Palanisamy UD, Goh BH, Yi WF, Chan KG, et al. Streptomyces gilvigriseus sp. nov., a novel actinobacterium isolated from mangrove forest soil. Antonie Van Leeuwenhoek 2015;107:1369-78.

34. Goodfellow M, Stanton LJ, Simpson KE, Minnikin DE. Numerical and chemical classification of Actinoplanes and some related actinomycetes. J Gen Microbiol 1990;136:19-36.

35. Nonomura H. Key for isolation and identification of 458 species of the Streptomycetes included in ISP. J Ferment Technol 1974;52:78-92.

36. Dash BK, Rahman MM, Sarker PK. Molecular identification of a newly isolated Bacillus subtilis BI19 and optimization of production conditions for enhanced production of extracellular amylase. BioMed Res Int 2015:1-9. Doi:10.1155/2015/859805.

37. Gopinath SCB, Anbu P, Md Arshad MK, Lakshmipriya T, Voon $\mathrm{CH}$, Hashim $\mathrm{U}$, et al. Biotechnological process in microbial amylase production. BioMed Res Int 2017;1-9. https://doi.org/10.1155/2017/1272193

38. Syed DG, Agasar D, Pandey A. Production and partial purification of amylase from a novel isolate Streptomyces gulbargensis. J Ind microbiol Biotechnol 2009;36:189-94.

39. Hwang SY, Nakashima K, Okai N, Okazaki F, Miyake M, Harazono $\mathrm{K}$, et al. Thermal stability and starch degradation profile of amylase from Streptomyces avermitilis. Biosci Biotechnol Biochem 2013;7:2449-53.

40. Moghbeli M, Noshiri H. Isolation of a native Bacillus licheniformis amylse producer from the hot source of semnan. J Microbial World 2009;2:155-60.

41. Kafilzadeh F, Dehdari F. Amylase activity of aquatic actinomycetes isolated from the sediments of mangrove forests in South of Iran. Egypt J Aquat Res 2015;41:197-201.

42. Khusro A, Barathikannan K, Aarti C, Agastian P. Optimizaiton of thermo-alkali stable amylase production and biomass yield from Bacillus sp. Under submerged cultivation. Fermentation 2017;3:73.

43. Singh S, Singh S, Bali V, Sharma L, Mangla J. Production of fungal amylases using cheap, readily available agriresidues, for potential application in Textile industry. BioMed Res Int 2014;214-9. http://dx.doi.org/10.1155/2014/215748 
44. Simiar AA, Qureshi AS, Khushk I, Haider Ali C, Lashari S, Bhutto MA, et al. Production and partial characterization of amylase enzyme from Bacillus sp. BCC 01-50 and potential applications. BioMed Res Int 2017:9. https://doi.org/10.1155/2017/9173040.

45. Krishma M, Radhathirumalaiarasu S. Isolation, identification and optimization of alkaline amylase production from Bacillus cereus using agro-industrial wastes. Int J Currt Microbiol Appl Sci 2017;6:20-8.

46. Naragani K, Muvva V, Munaganti R, Hima Bindu B. Studies on optimization of amylase production by Streptomyces cheonanensis VUK-A isolated from mangrove habitats. J Adv Biol Biotechnol 2015;3:165-72. 